\title{
Recognizing Victims as Political Actors: Expanding a More Complex Identity
}

JOHANNES LANGER*

The Politics of Victimhood in Post-Conflict Societies: Comparative and Analytical perspectives by Vincent Druliolle and Roddy Brett (Eds.). Palgrave Macmillan, 2018.

A central claim of transitional justice is to be victim-centered. The participation of victims has increased over the years and they are, by now, considered as protagonists who cannot be ignored any longer in a peace processes and transitional justice mechanisms in post-conflict societies (Mendez, 2016). And yet, victims continue to be simplistically portrayed as innocent, pure, lack of responsibility and with a moral superiority -instead of constructing a "complex victim" (Bouris, 2007). In contested narratives that typically emerge already during armed conflict and continue to play out in post-conflict situations, victimhood is used by the different sides in order to have more benefits on their end. In short, victimhood is not only a moral and legal issue but is very much political. ${ }^{1}$

The increasing recognition that there are different forms of victimhood has been laid out, not least in the 2016 special issue of the International Journal of Transitional Justice. However, who is a victim in the first place? Legal definitions have dominated the field, typically from the United Nations and the respective national laws in post-conflict countries. But

\footnotetext{
* Independent researcher based in Hamburg, Germany. E-mail: langerjohannes@gmail. com

1 For a legal debate about victims, the volume of Bonacker and Safferling (2013) is useful. Vanfraechem, Pemberton and Ndahinda (2014) have come up with a particularly encompassing book about victims and justice with ways forward towards reconciliation.
} 
what to do when several victim groups have claims to victimhood and face competition among themselves, who should be heard and prioritized? These are difficult challenges that do not have straight-forward answers.

The volume "The Politics of Victimhood in Post-Conflict Societies" is a book that is long overdue to address these issues. The editors, Vincent Druliolle and Roddy Brett, rightly claim that the victim as a political actor still has not been sufficiently considered within the transitional justice literature, thus they follow the call of Garcia-Godos $(2016,357)$ to fill that void, that challenges implicit assumptions about victims as just passive or apolitical actors. Four main contributions of this book are identified: 1) differentiating between victims and victimhood instead of taking the victim identity for granted, 2) analyzing victims as public figures and political actors, 3) the politics of victimhood and 4) victims as agents of change in times of transition. Druliolle and Brett assume that victimhood is socially and politically constructed, and their focus is about the political mobilization of victims that can ultimately allow them to be change agents instead of just passive subjects.

The framing of the book is insightful as it directs the reader into the complex questions surrounding victims. The proposed differentiation between victimhood and the politics of victimhood provides more clarity to this debate: on the one hand, discussing the role and identity of victims in post-conflict societies, while on the other hand, exploring the process of defining, negotiating and contesting the meaning of victimhood. Moreover, the question of who is defining a victim —other actors or a result of self-identification—is addressed as a potential tension. Examples in the introductory chapter are the gendered dimension of victims, particularly with non-female victims of sexual violence, but also the, sometimes, blurry lines between victims and perpetrators as it has been increasingly recognized to have a more nuanced understanding.

The structure that follows the introduction are eleven empirical chapters with case studies from around the world that elaborate the political construction of victims during conflict that are in turn organized in 
three parts. The first part has five chapters and is about defining victims and victimhood that provide a range of possibilities of who constitutes a victim and how victimhood is experienced. The second part called "victims in the political arena" has a focus on the political role of victims; although one would expect most contributions being situated within that part, there is one chapter less than in the defining part 1. The assumptions are on the one hand that victims can be analyzed like any other political actor, while on the other hand the mobilization of victims can produce competitive victimhood. Finally, the third part titled "Democratization, Peace Processes and Victims" is covering the victim's agency in times of transition and somewhat surprisingly the "impact" of victims on transitional justice processes, but only includes two chapters. While Brett's chapter does certainly fit very well into part 3, it is a pity that further contributions have not been included here.

Four chapters stand out: The politics of who is perceived as a real victim (or not) is particularly well laid out in De Waardt's chapter on Peru (chapter 6). She examines the negotiations in the Peruvian public of who constitutes a victim and who is sidelined through an analysis of key victim's associations in the country. The author shows how these initiatives transformed from support groups to social advocacy groups that have taken up the international human rights discourse. Nonetheless, the suspicion among victims' groups is so big that no unity seems to be possible, showing how contested processes of victims' acknowledgement can turn out when the economic and political elite has captured the debate. The chapter of Hronesova (chapter 7) about victim associations in Bosnia uses the social mobilization theory and a rationalist perspective to show the success and failure of two victim groups. She argues that she has developed a new theoretical lens (p. 180) thanks to her findings of victims' organizations and how they were able (or not) to bring their agenda on the policy-making level. Hronesova's contribution is a good way forward to explain variation while identifying with critical scholarship in the transitional justice field.

Breen-Smyth's (chapter 9) discussion on victims is the most reflective contribution of the book and, while drawing from the Northern Ireland case, also other examples are used to analyze the experience 
of suffering of war veterans or the Afro-American victimization in the U.S. context, and the conclusion that showing moral worth and value and taking up the role as a citizen again is the most powerful form of victims' resistance. Burkhardt-Vetter's (chapter 10) analysis on competitive victimhood discusses the empirical analysis of the exchange of victim's experiences from Israel and Palestine. The focus on dialogical remembrance is important for her, even though she also shows the limits to get out of the box of victimhood in order to recognize the Other. Even though it could have been helpful for her to engage in more traditional conflict resolution literature (e.g. Ron Fisher, Joe Montville), her conclusion that the focus on humanity instead of victimhood to move forward is certainly worth to further explore in the future.

The topic of political victims and victimhood is, of course, of high relevance for the Colombian context in its current implementation of the integral system of transitional justice. This volume contributes a whole chapter to Colombia with Roddy Brett's insightful analysis about the inclusion of victims in the peace process negotiations between the Revolutionary Armed Forces of Colombia (FARC) and the Colombian government. The impressions of victims participating at different stages during the negotiations provide the possibility for the reader to better understand the complexities and the significance of such a participation for victims. Despite Brett's transparency in informing that UNDP sponsored his research, one feels that a more critical approach towards the institutional process could have been helpful for the reader to further understand the complexities of victim participation in a peace negotiation and the contested public debates.

It is interesting that, besides the introductory chapter, Bouris' (2007) notion of "complex political victims" has not been picked up by any other author-in contrast to contributions elsewhere, like Bernath (2016). The same is true about the pronouncement of Garcia-Godos (2016) that a "victims-turn" took place in transitional justice. One would assume that this volume would be part of such a turn. Yet, besides the editors in the introduction, nobody is actively mentioning or discussing such a turn in this volume; ironically not even 
Garcia-Godos herself is mentioning this turn although her chapter is prominently placed as the first empirical chapter in the first part of the volume with the intent to define victims and victimhood in the Latin American context. After all, is this turn not real? This volume would be the proof that the attention to victims is here to stay in the transitional justice and peacebuilding literature without a doubt, but maybe a "victims-turn" has proven to be too strong of a term.

The book is an important contribution and exploration about the more political aspects of victims and victimhood. Due to the limited theoretical framing in the introductory chapter, the subsequent chapters are quite diverse, interesting by themselves but do not show a clear way forward regarding a research agenda on politics and victims. This lack of a way forward is clearly expressed in what is not in the book: a conclusion where the general learnings of the chapters are summarized and a path forward is discussed. Missing such conclusions shows either the lack of time or too diverse approaches in a book that would be an overall guide for the reader.

As in so many other books on transitional justice that aim to show comparative cases, this one put its spotlight on Latin America (four out of eleven empirical chapters). While other books have a strong focus on Africa too, "The politics of victimhood" only includes one case (Rwanda) but rather four chapters on Europe. Asia and the Middle East are, as all too often, neglected with just one case. What seems to be odd is that Spain is included two times. While there has been a lack in the English-speaking transitional justice literature on Spain, other cases could have provided a more interesting insight about the politics of victimhood as well, e.g. Sri Lanka, South Korea, East Timor, Tunisia or Morocco. These case studies could have allowed to address victimhood after victor's justice (Sri Lanka), competing victimhood between former freedom fighters and the civilian population after decolonization (East Timor) and case studies coming out of more recent dictatorships (Tunisia). Thus, it is the more "classic" cases within the transitional justice that are covered and missing out the chance to allow for further complexity within the debate on victims and victimhood. Ultimately, it would have been cases that would have 
fit particularly in the third part of the book that focuses on victims in transitions that only has two chapters included.

As the book market is ever more frantic in publishing, the quality of editing is sometimes questionable. While most chapters are well revised, some other chapters suffer of (minor) grammatical or editorial mistakes; of this publishing house, a higher quality can be expected. At the end of the book, an index is included. That is supposedly helpful for a reader to orient oneself, but when only 30 entries are added on 2.5 pages in an incoherent way, it is indeed better to exclude an index. Regarding the selection of authors, it is a pity that not more diversity was possible as ten of the twelve chapters have been written by European authors and two other chapters from Latin Americans. For sure, more diversity regarding the background of authors as well as the inclusion of institutions of the global south can help to broaden the discourse and debate. ${ }^{2}$

In sum, "The Politics of Victimhood in Post-Conflict Societies" provides an insightful read and certain chapters particularly stand out that can move the debate forward of providing more complexity to the victims' individual and collective identity. The diversity of the contributions show how many approaches are possible to address the issue and this book is certainly not the last input on the topic. It is more than "a collection of individual chapters" (p. v) but neither is there a coordinated effort to show a way forward of how to address the topic. Druliolle and Brett present an important input to the debate on victims in the transitional justice and peacebuilding field that is particularly relevant for all scholars discussing countries coming out of armed conflict or authoritarian regimes as well as insights for practitioners as well of how to better design their interventions.

\footnotetext{
2 An example is the volume edited by Fabio Diaz (2018) where all contributors are from the global south.
} 


\section{References}

Bernath, J. (2016). "Complex political victims" in the aftermath of mass atrocity: Reflections on the Khmer Rouge tribunal in Cambodia. International Journal of Transitional Justice, 10(1), 46-66.

Bonacker, T. \& Safferling, C. (Eds.) (2013). Victims of international crimes: An interdisciplinary discourse. The Hague: Asser Press.

Bouris, E. (2007). Complex political victims. Bloomfield, CT: Kumarian Press.

Diaz, F. A. (2018). Truth, justice and reconciliation in Colombia: Transitioning from violence. London: Routledge.

Garcia-Godos, J. (2016). Victims in focus. International Journal of Transitional Justice, 10(2), 350-358.

Mendez, J. E. (2016). Victims as protagonists in transitional justice. International Journal of Transitional Justice, 10(1), 1-5.

Vanfraechem, I., Pemberton, A. \& Ndahinda, F. M. (2014). Justice for victims: Perspectives on rights, transition and reconciliation. London: Routledge. 